\title{
PARAPLEGIC PARA-ARTICULAR CALCIFICATION
}

\author{
BY \\ GEOFFREY STOREY \\ North-East Metropolitan Hospital Board \\ AND \\ W. S. TEGNER \\ Department of Physical Medicine, The London Hospital
}

(RECEIVED FOR PUBLICATION JANUARY 14, 1955)

Abnormal ossification or calcification of the joints is seen in osteo-arthritis, Charcot's joints, and the Pellegrini-Stieda syndrome; less well-known is that seen in the soft tissues not involving the joint surface, consequent upon disease or injury of the nervous system. This condition has a variety of names: "para-osteo-arthropathy" (Dejerine, Ceillier, and Dejerine, 1919); "neurogenic ossifying fibromyopathy" (Soule, 1945); "paraplegic neuro-arthropathy" (Solovay and Solovay, 1949); "paraarticular ossification" (Freiburg, 1952).

This condition has been described particularly in paraplegia caused by trauma to the nervous system. Indeed, 40-50 per cent. of patients with traumatic paraplegia have been described by various authors as suffering from abnormal ossification or calcification round the hip or knee joints; these are the joints usually involved, but the condition may occur anywhere below the level of the neurological lesion. However, calcification and ossification do not follow only trauma of the central nervous system. Voss (1937) gives a list of conditions with which they may be associated. This includes lesions not only of the brain and spinal cord, but also of the peripheral nerves.

The present paper describes two cases of paraarticular calcification following encephalo-myelitis, and one following craniotomy for a cerebral tumour. In order to form some idea of the incidence, we have examined the radiographs of the hip joints of 51 patients with other nervous diseases causing paraplegia or immobility (Table). Whether ossification or calcification results appears to depend partly on the stage of development (Brailsford, 1941) and partly on the state of the local blood supply (Watson Jones and Roberts, 1934).
TABLE

INCIDENCE OF ABNORMAL CALCIFICATION IN VARIOUS NEUROLOGICAL CONDITIONS

\begin{tabular}{|c|c|c|c|}
\hline Diagnosis & & No. of Cases & No. showin $\bar{P}$ \\
\hline $\begin{array}{l}\text { Paraplegia in the Old ... } \\
\text { Disseminated Sclerosis } \\
\text { Cerebro-vascular Accidents } \\
\begin{array}{l}\text { Post-craniotomy, Cerebral } \\
\text { or Abscess .. }\end{array} \\
\begin{array}{l}\text { Spinal Cord Tumour } \\
\text { Congenital Spasticity }\end{array} \text {. } \\
\begin{array}{l}\text { Post-encephalitis } \\
\text { Myelitis . . }\end{array} \\
\text { Trauma to Spinal Cord }\end{array}$ & $\begin{array}{ll}\cdots & \cdots \\
\cdots & \cdots \\
\text { Tumour } \\
\cdots & \cdots \\
\cdots & \cdots \\
\cdots & \cdots \\
\cdots & \cdots \\
\cdots & \cdots\end{array}$ & $\begin{array}{r}14 \\
10 \\
6 \\
9 \\
9 \\
3 \\
3 \\
3 \\
2 \\
1\end{array}$ & 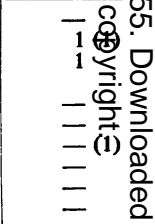 \\
\hline Total .. & . & 51 & $2(2) \subseteq$ \\
\hline
\end{tabular}

(Figures in brackets indicate cases with other abnormalities)

\section{Case Reports}

Case 1, a male, aged 39, had an attack of measles ib April, 1951, followed by encephalo-myelitis. During. this time he developed a confusional state, with weakness of the lower limbs; but no details of his neurologicat condition are available. He remained confused and immobile for 6 weeks, and developed several bed sores Suprapubic cystotomy had to be performed because of retention of urine. The mental condition improves. rapidly after this, and skin grafting over the bed soress was performed in October, 1951.

In December, 1951, the patient was able to get up and walk with help, but developed swelling of the right kneau Although he now had rectal and urinary control, he developed painful frequency of micturition, and cystoe scopy showed two large calculi in the bladder.

Examination.-In December, 1951, there was no ment abnormality. There was limitation of all movements of both hips, an effusion into the right knee, with slighs limitation of flexion and extension, and limitation of 
flexion of the left knee. There were no gross abnormalities in the central nervous system, but both ankle jerks were very brisk, and there was a possible extensor plantar response in the right. Other systems were normal. $X$-ray examination showed calcification round both hips and knees, with calculi in the bladder (Fig. 1).

Serum acid phosphatase

Serum alkaline phospha-

Blood urea

$\begin{array}{lllll}\text { Serum calcium } & \ldots & \cdots & 36 & \mathrm{mg} . / 100 \mathrm{ml} \text {. serum }\end{array}$

Plasma inorganic phos-

$\begin{array}{lll}\text { phorus } \quad . & . . & 5.2 \mathrm{mg} . / 100 \mathrm{ml} \text {. serum }\end{array}$

Suprapubic lithotomy (May, 1952) was performed, with relief of the urinary symptoms. Walking improved with re-education, and he was able to walk 2 miles after discharge from hospital. When last seen in June, 1953, he had no symptoms except for his difficulty in walking, and the physical signs remained the same.

The $x$-ray appearance of the hips and knees had not changed.

Case 2, a man, aged 29, began to have double vision, headaches, and numbness of the right arm and leg in July, 1951; 4 months later he was found to have bilateral papilloedema, slight right lower facial weakness, and right-sided spastic hemiparesis, with right extensor plantar response. There was also analgesia to cotton wool and pin prick on the left side, and impaired position sense of the left hand. He was admitted to hospital, and a craniotomy was performed. A mixed glioma was found in the right temporo-parietal region. A portion of the tumour was removed, and deep $x$-ray therapy was given.

The post-operative period was difficult, and the patient was immobile for some time, but made a satisfactory recovery, and was discharged 6 weeks after the operation. There was no evidence of any severe bed sore.

Examination.-On February 4, 1952, he showed only a slight left hemiparesis, without sensory loss. There was, however, limitation of all movements of the hips, right more than left, and limitation of flexion of the left knee. $X$-ray examination showed bony trabeculae between the greater femoral tuberosities and the rims of the acetabulae (Fig. 2, overleaf) and calcification in the medial ligaments of both knees (Fig. 3, overleaf).

Serum calcium .. $\quad . . \quad 9.5 \mathrm{mg} . / 100 \mathrm{ml}$. serum Plasma inorganic phosphorus .. $\quad . .4 .8 \mathrm{mg} . / 100 \mathrm{ml}$. serum Serum alkaline phosphatase $\quad . \quad \ldots$

$6 \cdot 5$ K.A. units $/ 100 \mathrm{ml}$. serum With re-education, walking improved, and the range of joint movement increased, but the $x$-ray appearance remained unchanged. The patient then began to have generalized convulsions; he was re-admitted to hospital on March 3, 1953, with increasing drowsiness, and died 3 weeks later. Permission for necropsy was refused.

Case 3, a man, aged 25, began to complain of headache, with numbness of the legs in 1951 . He was admitted to hospital, and was found to have a flaccid paralysis of the left leg, nystagmus, and neck rigidity. He became drowsy, and developed retention of urine, for which a suprapubic cystotomy was performed. His mental condition gradually improved, but he developed incontinence of urine and faeces, with spastic paraplegia. A diagnosis of meningo-encephalitis was made. He was admitted to Black Notley Hospital, where, in spite of physical treatment, he developed flexion contractures of the hips and knees. At this time extensive new bone formation was found about the hip joints.

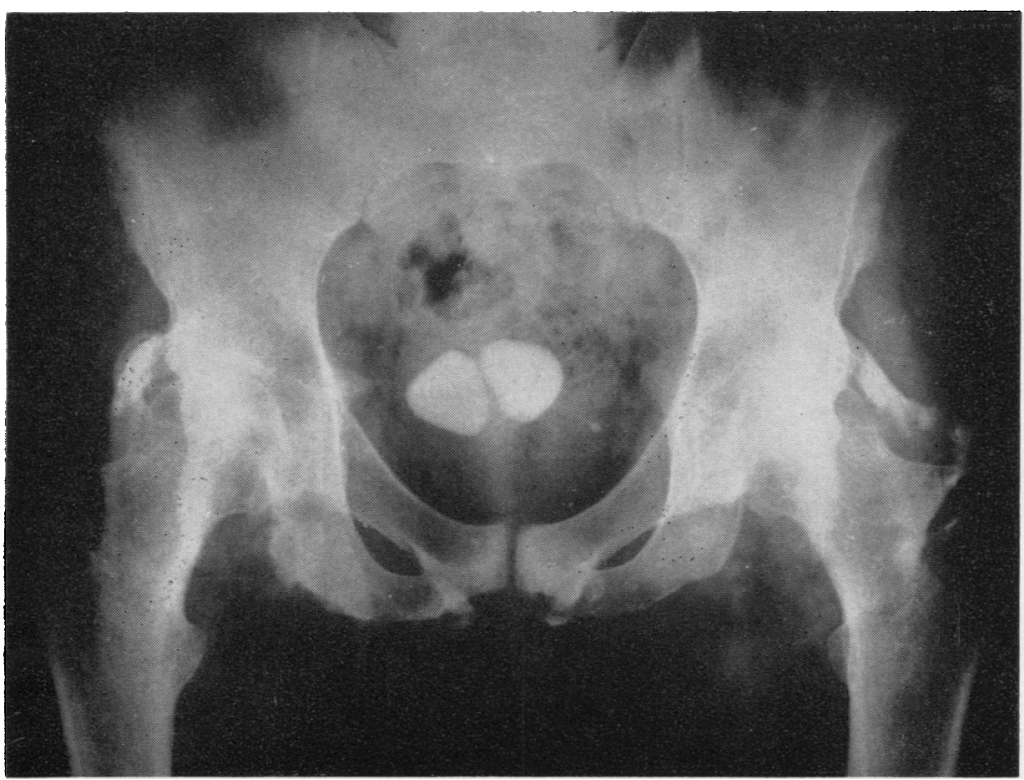

Fig. 1.-Case 1, calcification round hip joints with two calculi in bladder. 
Fig. 2.-Case 2, bony trabeculae round both hip joints.

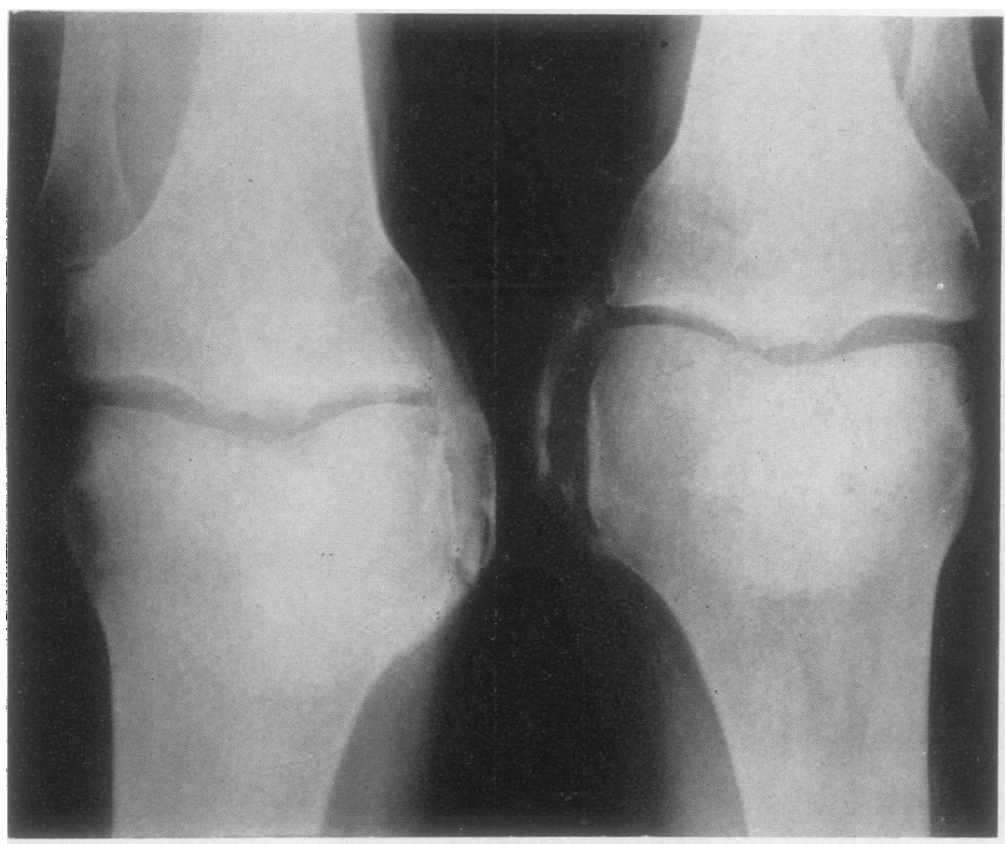

Fig. 3.-Case 2, calcification in media ligaments of knee joints.

He was discharged after 14 months' treatment, but was re-admitted in April, 1953, when an operation was performed on the right hip. He began to gain control over his bladder and rectum. Otherwise, he was paralysed in the lower limbs, and could move only his left toes.
Examination.-In December, 1953, there was spastico paraplegia, with flexion contracture of the hips an $\phi_{D}$ thighs, and analgesia over the lower trunk and thighs? The reflexes of the upper and lower limbs were very brisk. The patient's intelligence was retarded. Theres were extensive bed sores on both buttocks. 
Examination showed extensive new bone formation There was also new bone formation around the lower end of both hips, with subluxation of the right hip (Fig. 4). of the right femur in the quadriceps muscles (Fig. 5).

Fig. 4.-Case 3, bone formation round hip joints with subluxation of right hip.

Fig. 5.-Case 3, bone formation in lower end of right quadriceps muscle, left side normal.
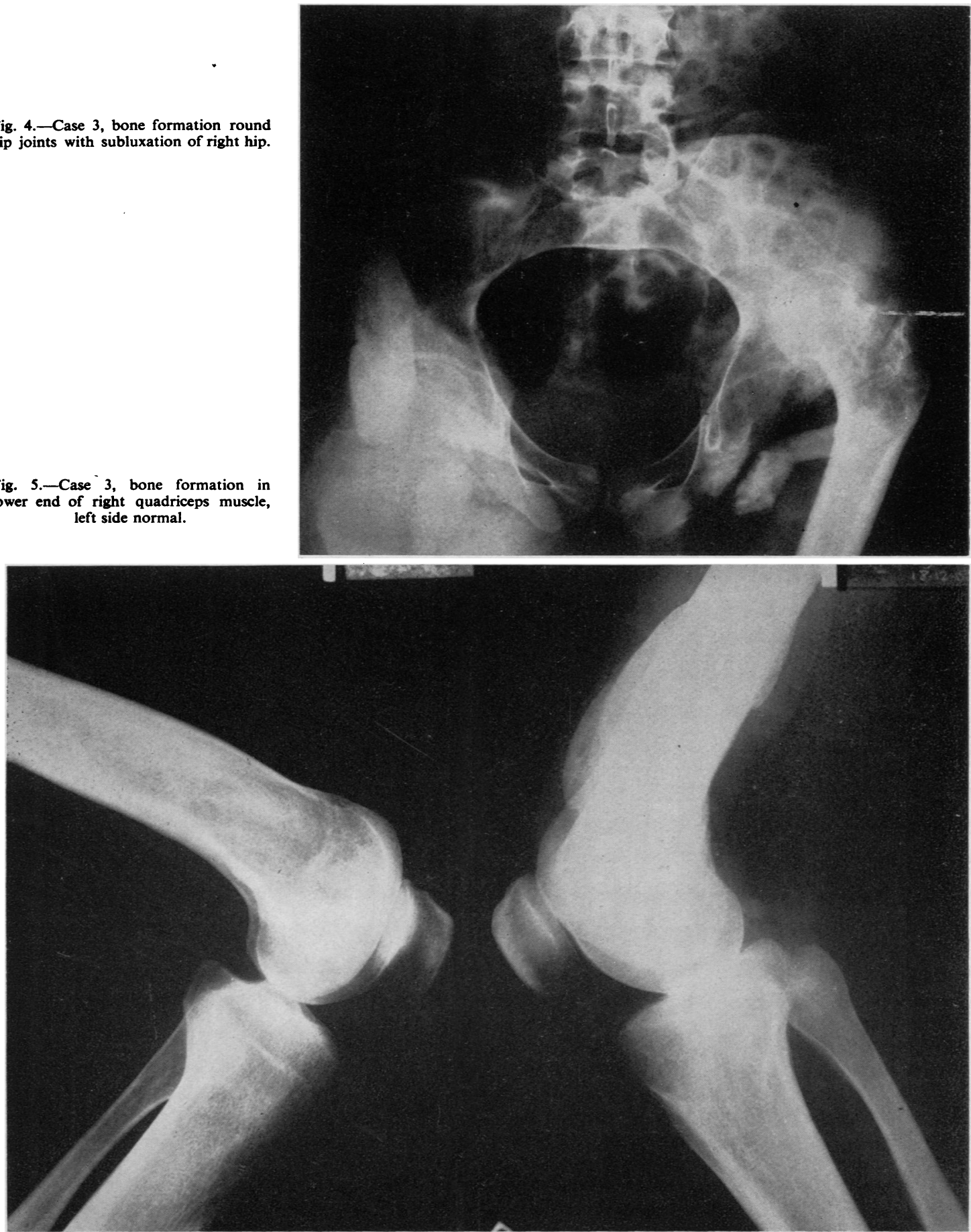
Serum calcium 11 mg./100 ml. serum

Plasma inorganic phosphorus ..

Serum alkaline phostase

$3 \cdot 1 \mathrm{mg} . / 100 \mathrm{ml}$. serum

$3 \cdot 8$ K.A. units $/ 100 \mathrm{ml}$. serum

Metabolic studies performed by Dr. Stuart Mason showed, on urine studies only:

Negative nitrogen balance (presumably due to immobility), but no abnormality in the calcium or phosphorus. Testosterone inhibited nitrogen drainage as expected, but had no effect on the calcium or phosphorus. Probably this is because the calcium and phosphorus were normal in the first place.

In order to determine the frequency of this condition we reviewed the $x$ rays of the hip joints of 51 patients with chronic nervous disorders, who were bed-ridden or immobile. These were mainly paraplegics, but, in view of the findings in Case 2 , we included a group of cases who had had a period of a month or more of immobility after craniotomy. The detailed diagnoses are shown in the Table.

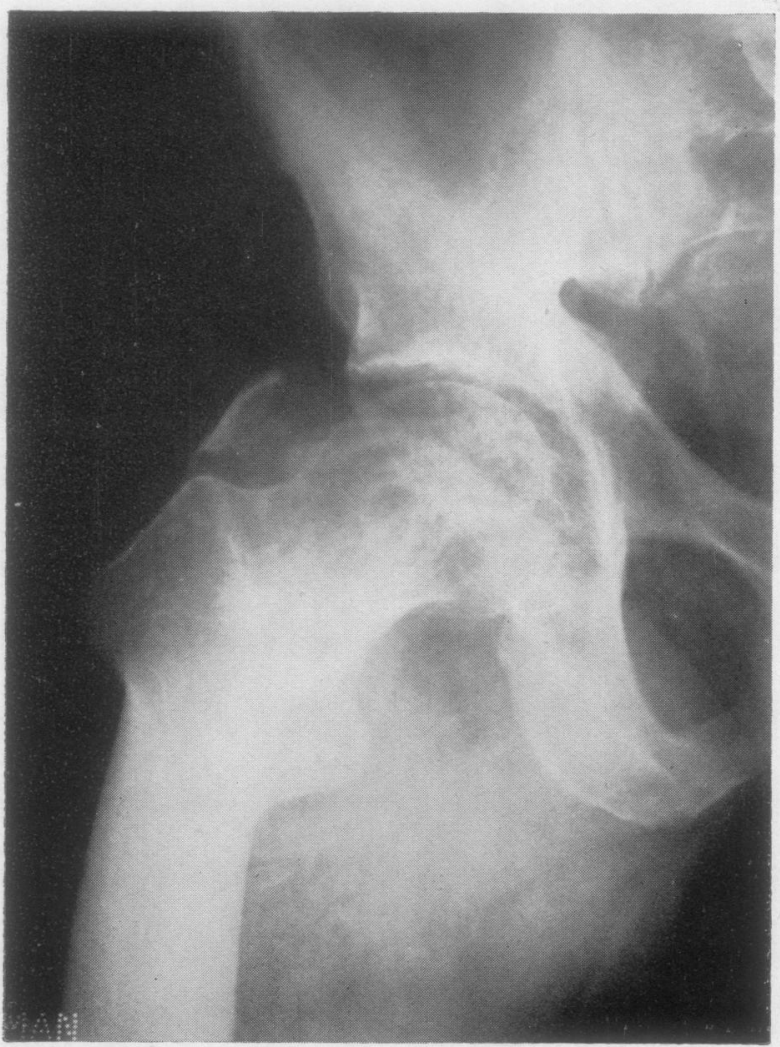

Fig. 7.- Small deposit of calcium near right hip in a man with paraplegia due to cerebro-vascular accidents.

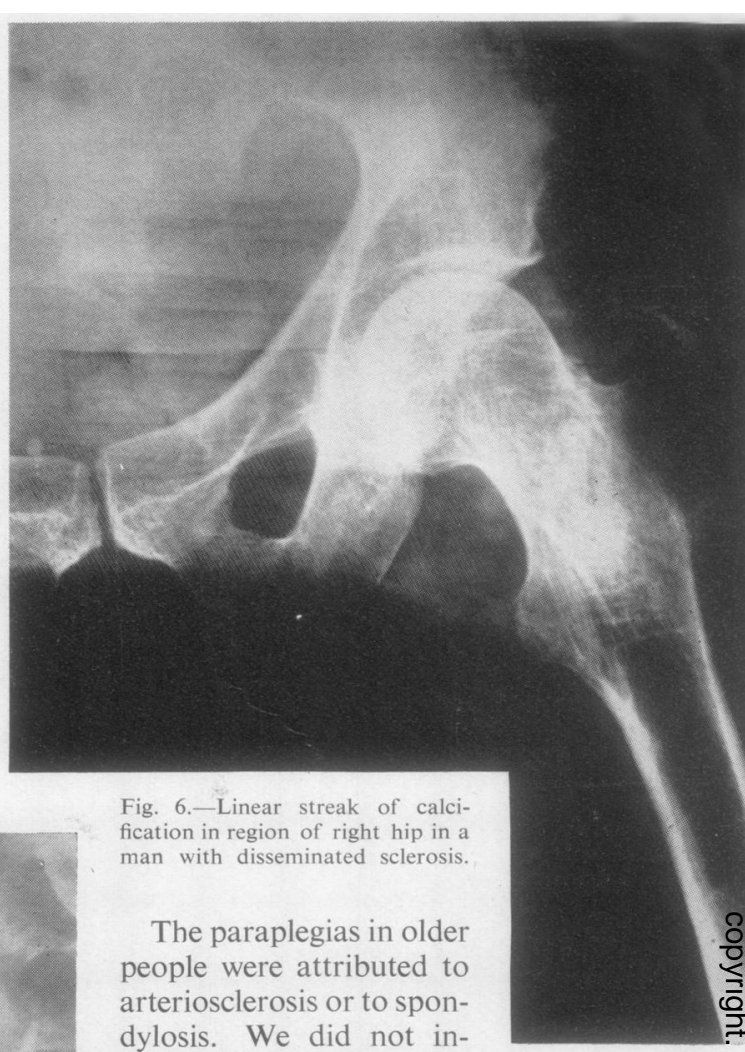

dylosis. We did not in-

clude any cases of Char-

cot's joints. The incidence of bed sores was요 often difficult to assess, as many had been bed- $\vec{F}$ ridden for years, and records were not always available for the whole period. However, al though small superficial bed sores were common large deep ones of the type seen in Cases 1 and $2 \stackrel{-}{0}$ were found in only four cases, and one of the⿳⺈ four had para-articular calcification. Amongo these 51 radiographs we found only two with ar: appearance similar to the condition we areo describing:

(1) A man, aged 59, had had disseminated sclero윽 sis for many years, with severe spasticity and ataxia. He had been unable to walk for 20 years, had been음 bed-ridden for 2 years, and had had deep bed sores for 6 months. $X$-ray examination showed linear cal- $\mathbf{O}$ cification in the region of the right hip (Fig. 6). Then patient died shortly after, and further investigations were not possible.

(2) A man, aged 77, developed a right hemiplegiaర following a cerebro-vascular accident in April, 19530 He had remained bed-ridden since then, and $\frac{\mathrm{D}}{\Phi}$ months later had developed spasticity of the left side with extensor plantar responses on both sides. An $x$ ray taken 9 months later showed small depositso round the right hip (Fig. 7). 
Two other cases showed different abnormalities:

(3) A woman, aged 40, with disseminated sclerosis, had a fracture of the pelvis.

(4) A man, aged 35, with congenital spastic paraplegia, had exostoses of the ileum.

These abnormalities appeared to result from spasticity, and not to be comparable with our other cases.

\section{Discussion}

Brailsford (1941) and Voss (1937) have described the sequence of events which occur in calcification and ossification of the soft tissues. Changes may be seen as early as 4 weeks after injury. These consist of the deposition of flocculent calcium, which forms into linear streaks, and in the second month undergoes organization, ectopic bone being formed subsequently. In para-articular ossification the ectopic bone formation may involve any of the soft tissues round the hip joint, the capsule, fascial planes, or muscles (Heilbrun and Kuhn, 1947); McNeur (1954), in one post-mortem study, found the calcifications mainly on the anterior aspect of the joint. In Case 1 the calcium appeared to lie in the ligaments of the hip joints, whereas in Case 3 the muscles were involved. The medial ligament of the knee joint is sometimes affected, producing an appearance similar to, but more extensive than, the Pellegrini-Stieda syndrome (Case 1). Abramson and Kamberg (1949) and Abel (1950) reported changes in the sacro-iliac joints in some cases, but this was not seen in any of ours.

The high incidence of para-articular ossification in traumatic lesions of the nervous system is well recognized: 49 per cent. (Dejerine, Ceillier, and Dejerine, 1919); 23 out of 62 cases (Soule, 1945); and 43 out of 99 cases (Heilbrun and Kuhn, 1947). Nevertheless, as has been mentioned, many other conditions may be associated. Three cases have been reported recently, after poliomyelitis (Freiburg, 1952), and McNeur (1954) has reported one case after myelitis, with two due to trauma of the spinal cord. It is of interest that Voss (1937) specifically mentions epidemic encephalitis, embolic encephalitis, myelo-encephalitis, and meningomyelitis, all rare lesions. Our Cases 1 and 3 seem to show that conditions of the encephalo-myelitis group are also liable to result in para-articular ossification. Our control group contained only two cases of myelitis, and one of trauma to the cord. The lesions studied in this group were mostly of gradual onset, and this may account for the infrequency with which we found abnormal ossification. Age may be another factor responsible for the absence of ossification, since our 51 patients were mainly elderly.
No satisfactory explanation of para-articular ossification has been found. Many regard the condition as related to Charcot's joints; Solovay and Solovay (1949) reported one case which later developed a condition indistinguishable from a Charcot's joint, and calcification is sometimes seen in the soft tissues surrounding a Charcot's joint of the hypertrophic type. But the two conditions are quite distinct, at least in the early stage. Charcot's joints, although found in a variety of nervous disorders, are mainly seen in tabes dorsalis and syringomyelia, whereas para-articular ossification is mainly seen in paraplegia resulting from trauma and encephalo-myelitis. Also, the factors generally regarded as important in the causation of Charcot's joints-sensory loss and trauma due to weight bearing (Eloesser, 1917)-do not appear to be necessary for the formation of para-articular ossification. Heilbrun and Kuhn (1947) regard pressure on the buttocks from prolonged immobility in bed as a possible traumatic agent, and absence of weightbearing may account for the preservation of joint surfaces. The aetiological factors responsible for a Charcot's joint have not been fully elucidated, and the trophic function of nerve fibres, although never demonstrated (Delano, 1946), cannot be entirely discounted. Liberson (1953) suggested that a lesion of the sympathetic nerve may be responsible.

A different line of argument suggests that an upset in calcium metabolism may be the cause. In the early stages of immobility there is a negative calcium balance, with mobilization of calcium from the skeleton, sometimes with formation of urinary calculi (Armstrong, 1944) as in Case 1. But paraarticular ossification occurs almost exclusively in patients immobilized by nervous disease, and the development of localized myositis ossificans, which Brailsford (1941) believes to be an allied condition, does not depend on immobility alone. We failed to demonstrate any abnormality in calcium balance in Case 3, but the test was performed 2 years after the onset of the condition. Freiburg (1952), because of variation in the serum alkaline phosphatase reading in one case, believed that there might be a transient upset in calcium metabolism, but Soule (1945) found no difference in calcium levels between cases with ossification and otherwise similar cases without, although the plasma organic phosphorus and serum alkaline phosphatase values differed slightly. The calcium, phosphorus, and phosphatase levels were not significantly abnormal in our three cases. A transient renal failure may be a factor, since para-articular calcification was reported in a case of chronic renal failure without paraplegia by Levin and Genovese (1950). 
The presence of bed sores has been held to be important. Most cases developing ossification have bed sores, and Heilbrun and Kuhn (1947) and McNeur (1954) believe that the local sepsis may alter the local circulation, and so create conditions suitable for calcification. Soule (1945) found that all his cases with para-articular ossification had bed sores, but that these were also present in many other cases. Three of our cases had severe bed sores, but bed sores were not found about the knees in the patient (Case 1) who showed calcification round the knee joints.

There thus appears to be no satisfactory explanation why one case is affected and another not; Solovay and Solovay (1949) could only suggest that in some patients an individual diathesis might predispose them to the development of ossification.

\section{Summary}

Three cases of para-articular calcification or ossification are described: two of encephalomyelitis, and one of cerebral neoplasm with craniotomy.

In a series of 51 patients with chronic nervous disorders, only two had slight calcification round the hip joints. Patients with paraplegia due to trauma of the central nervous system and encephalomyelitis appear to be particularly liable to develop this complication, which develops mainly in younger people.

The aetiology of the condition is discussed. No satisfactory explanation has yet been found.

\section{REFERENCES}

Abel, M. S. (1950). Radiology, 55, 235.

Abramson, D. J., and Kamberg, S. (1949). J. Bone Jt Surg., 31A, 275.
Armstrong, W. D. (1944). Fed. Proc., 3, 201.

Brailsford, J. F. (1941). Brit. J. Radiol., 14, 320. Dejerine, ., Ceillier, A., and Dejerine, Y. (1919). Rev. Neurol.,

Delano, P. J. (1946). Amer. J. Roent., 56, 189.

Eloesser, L. (1917). Ann. Surg., 66, 201.

Freiberg, J. A. (1952). J. Bone Jt Surg., 34A, 339.

Heilbrun, N., and Kuhn, W. G. (1947). Radiology, 48, 579.

Jones, R. Watson, and Roberts, R. E. (1934). Brit. J. Surg., 21, 461. Levin, R. T., and Genovese, P. D. (1950). Amer. J. Roent., 64, 423. Liberson, M. (1953). J. Amer. med. Ass., 152, 1010.

McNeur, J. C. (1954). Proc. roy. Soc. Med., 47, 14.

Solovay, J., and Solovay, H. U. (1949). Amer. J. Roent., 61, 475.

Soule, A. B. (1945). J. Neurosurg., 2, 485.

Voss, H. (1937). Fortschr. ad. Gebd. Roëntgenstahlen, 55, 423.

\section{Calcification paraplégique para-articulaire \\ RÉSUMÉ}

On décrit trois cas de calcification ou ossification paraarticulaire: deux d'encéphalo-myélite et une de néoplasme cérébral avec craniotomie.

Dans une série de 51 malades manifestant des troubles nerveux chroniques, seulement deux d'entre eux présentaient une légère calcification autour de l'articulation de la hanche. Les malades ayant une paraplégie consécutive à un traumatisme du système nerveux central et à l'encéphalo-myélite semblent être particulièrement susceptibles de souffrir cette complication qui attaque surtout des personnes plutôt jeunes.

On discute l'étiologie de cette affection qui n'a pas encore d'explication satisfaisante.

\section{Calcificación paraplégica para-articular SUMARIO}

Se describen tres casos de calcificación o de osificació para-articular: dos de encefalomielitis y un de neoplasm cerebral con craniotomia.

En una serie de 51 enfermos con disturbios nerviosos crónicos, sólo dos manifestaron una ligera calcificación alrededor de la articulación coxo-femoral. Enfermos con paraplegia consecutiva a un traumatismo del sistema nervioso central y a la encefalomielitis parecen particularmente susceptibles a esta complicación, que ataca generalmente personas jóvenes.

Se discute la etiología de esta afección, que todavía no tiene explicación satisfactoria. 